\title{
The International and the Construction of Opposition in Iran
}

\section{Thorsten Bonacker and Tareq Sydiq}

Iran has a long and storied tradition of protest and revolution. This tradition has been characterized by a range of diverse oppositional activities. The "Tobacco Protests" of the late nineteenth century, for example, brought together a successful alliance of clergy and bazaaris against the state (Moaddel 1994). Similarly, the beginning of the twentieth century saw a mobilization of socialist, feminist, and ethno-political groups as well as regionalist and nationalist politicians (Cronin 2007; Najmabadi 2007; Sharifi 2013; Atabaki 2003). The 1979 Iranian revolution once again brought the diversity of these opposition forces to the surface when a diverse alliance, united in its desire to see the end of the regime, proved capable of overthrowing the Shah (Foran 1994; Kurzman 2004). During the first years after the revolution, this oppositional diversity was reproduced within the political elite. This soon became a problem for the new rulers, and groups that differed from the new state ideology were quickly persecuted and marginalized (Schirazi 1998).

Nevertheless, the Iranian political elite continues to be characterized by pluralism, as do opposition groups beyond state institutions. Successive waves of protest since the 1990s have revealed myriad oppositional positions. These target a diverse range of issues, including socio-economic problems, the liberalization of public

\footnotetext{
T. Bonacker $(\bowtie)$

Zentrum für Konfliktforschung, Philipps-Universität Marburg, Marburg, Germany e-mail: thorsten.bonacker@uni-marburg.de

T. Sydiq

Zentrum für Konfliktforschung, Philipps-Universität Marburg, Marburg, Germany

e-mail: sydiq@staff.uni-marburg.de

(C) The Author(s) 2021

R. Ouaissa et al. (eds.), Re-Configurations, Politik und Gesellschaft des Nahen Ostens, https://doi.org/10.1007/978-3-658-31160-5_5
} 
morality, or enhanced rights for minorities. The Arab Spring witnessed an equally diverse array of groupings unified by aversion to autocratic governments, even if this diversity did not necessarily lead to the overthrow of the president, as was the case in Tunisia and Egypt. Collective protest of this kind has been described as a paradigm of contentious politics. Since the end of the Cold War, autocracies in eastern and south-eastern Europe, Latin America, East Asia, and Africa have not been spared from these "waves of popular discontent" (Gerges 2015, p. 10).

With good reason, political and regional research in this area has traditionally shown a particular interest in the dynamics of regime change. However, the initial euphoria for democratization and regime change has given way to an interest in the resilience of autocracies and the re-configuration of patterns of domination (Carothers 2002). At the same time, there has been an appreciable increase in the number of studies dealing with the diversity of political opposition (Harders and König 2013). For some time, political opposition in autocracies was considered a marginal phenomenon. Since the 2000s, however, a growing body of scholarship has highlighted the role of opposition forces in autocracies. As before, there has been a particular focus on questions around democratic transition and political organizations, such as parties, civil society groups, and social movements. This has resulted in the development of new terminology, such as the term "non-movement" (Bayat 2013), along with the extension of existing civil-society terminology far beyond its original scope (Aarts and Cavatorta 2013).

In autocracies, however, opposition can involve a broad range of different actors, forms, and issues. It can be linked to various demands: for greater political and social participation, for changes in the corridors of power, or for constitutional reforms. However, none of this necessarily has to follow the assumed logic of a democratic transition characterized by greater inclusion and comprehensive participation. Such developments could well proceed according to a rhetoric of exclusion or aggressive nationalism. They may even be embedded in clientelist or nepotistic patterns of social relationships. Likewise, the forms of opposition vary. They may range from parliamentary activity to civic engagement to public or virtual forms of protest. But they might also include private and everyday forms of opposition that are not necessarily limited to what is publicly visible and articulated.

Obviously, depending on its context in an autocracy or democracy, political opposition follows different rules, is subject to different conditions, and has a different function for the regimes in power. All the more intriguing, then, are the manifold ways of constructing opposition in autocracies. So far, this has received little scholarly attention, especially from a conceptual point of view. This article therefore focuses on the construction of opposition by political actors. How is a 
critical attitude toward the regime explained? How are demands for reform justified? On what basis does a person identify as "oppositional"? As these questions indicate, we are not as concerned here with the institutional role of political opposition in a given system or the role played by this opposition in systematic change. Instead, we are interested in how actors mark their oppositionality and construct it as a social identity. This does not necessarily happen in public - that is, in the context of contentious politics. Indeed, it often occurs in everyday interactions that take place at the fringes of, or even beyond, the public spaces controlled by the autocracy. This is precisely the focus of our chapter. In particular, we place a special emphasis on internationalism as a symbolic resource for the construction of opposition. To date, this element has generally been neglected in research.

Overall, then, this essay aims to outline a conceptual perspective on the comparative exploration of social and discursive constructions of opposition in autocracies, emphasizing the role of everyday interactions in this process. The next section looks to anchor our perspective in the existing body of contemporary autocracy research. We will then develop the thesis that the development of opposition is in no small part due to externalization-that is, to different references to the "international" real. Next, we will distinguish between three types of international reference points that can be used to mark opposition. We use the example of Iran in order to illustrate these international reference points for the construction of oppositionality. This case study is based on research conducted as part of a dissertation project on everyday politics and participatory mechanisms in autocracies. Data was collected during three research visits in 2017 and 2018 in the form of participant observations, field notes, and semi-structured interviews. Additionally, impromptu drawings and maps were employed to complement field notes where appropriate. Our research interest in everyday interactions and private or semi-public discourses resulted in a focus on participant observation in particular, as well as an embeddedness of the researcher in the context being researched, because they allowed for field access based on trust and interpersonal relations. This paper employs data collected during that research in order to illustrate dynamics of opposition construction.

\section{Opposition in Autocracies}

Opposition cannot be taken for granted in any political system. It is by nature relative: "opposition can only be spoken about in the context of distinctions. An opposition differs from what it opposes" (Luhmann 1989, p. 13). Opposition is 
thus a socially constructed form of political communication. It is distinguished by whether it aligns with the government's position or, in fact, sees itself as an alternative to that position. As Luhmann suggests, this simple coding of political communication allows for a very high degree of complexity and diversity. It also gives rise to some particularly interesting questions. How is opposition constructed in the context of political discourse? How do actors situate their identity in this context, while modifying that identity on a case-by-case basis? Clearly, oppositionality is by no means a fixed subjective position. It is established by and updated in the course of continuous political communication, and it is closely connected with the idea of political alternatives.

Formal and informal rules about the distinction between government and opposition differ according to the political system. For autocracies, Albrecht has stated that opposition can be understood as a "political institution with decisive organizational capacities whose interactions with the regime are of a competitive nature, yet are based on a minimum degree of mutual acceptance" (Albrecht 2005, p. 379). However, this definition applies only to an authorized and in some ways already incorporated form of opposition, which sometimes can also be co-opted by the government (Buckles 2019). From a broader perspective, however, it is possible to distinguish between different levels of opposition based on what they advocate, from reform to a change of government to a systemic change.

The political science of autocracy research has repeatedly pointed to the variety of institutionalized and informal forms of opposition in non-democratic systems. This applies in particular to the variant of competitive authoritarianism. In such a system, elections play an important role in the legitimation of political rule and the co-option of political elites (Levitsky and Way 2002). To be sure, democratic institutions are circumscribed or damaged in electoral or competitive autocracies. But these institutions must still be taken seriously by incumbents if they wish to avoid a crisis of legitimacy (Burnell 2006).

Iran's political system is this type of competitive autocracy. Elections are central to the legitimacy of the regime, and they are anchored in the constitution, even though the conditions governing them were altered in the regime's favor after the revolution (Schirazi 1998). Moreover, elections in Iran provide an instrument for subsuming various political currents within the system in a way that contributes to the stabilization of that system. "The factional characteristic of the Iranian party system is of more relevance to the electoral process, as the results can balance the power struggle toward more 'reformist,' 'conservative,' 'radical,' or 'pragmatic' factions in legislative, presidential, or Assembly of Experts elections" (Zaccara 2014, p. 158). 
In recent research on autocracies, there has been a general shift towards analyzing how such regimes legitimize themselves. The period from the 1990s to the early 2000s was dominated by a paradigm of transition. However, the obvious consolidation of central elements of authoritarian rule in the years after the Cold War gave rise to a new question: how was it possible for authoritarian regimes to secure legitimacy? This body of scholarship has been mirrored by other studies emphasizing the oppositional role of civil society and activist groups in autocracies. As Lewis (2013) has shown, their significance is apparent not least in their capacity to produce "counter-hegemonic" and alternative narratives that challenge the regime's legitimacy. In this context, research has also focused on spheres beyond official politics, such as "shadow markets" (Dukalkskis and Gerschewski 2017; Joo 2014) or sites of cultural and literary production (Elseewi 2011). Meanwhile, works such as those by Scott (1990) or Bayat (1997) have shown that, in autocracies, opposition in the sense of resistance often occurs beyond the public sphere, taking both private and informal forms (Vinthagen and Johansson 2013).

There thus exists a gamut of studies on everyday politics in autocracies and on the role of counter-discourses that explore actors' maneuvering room beyond formal channels of communication. But this body of scholarship raises numerous questions around how oppositionality in autocracies is constructed in practice. Lewis (2013), for example, speaks of strategies of "re-imagination"- - the oppositional process of re-articulating particular narratives. This opens up alternatives to official definitions of problems and the associated policies promulgated in order to tackle them. In effect, these are the kinds of discursive practices that produce opposition to the incumbent regime. Such practices are associated with demands for reform. These demands may be more extensive or less so, and they may be linked to very different political—and indeed, anti-democratic — positions.

Below, we present a conceptual proposal that focuses on a particular form of discursive practice for the construction of political opposition, which consists of making reference to an external, international environment. This international dimension - "the International"-is invoked in order to articulate demands for reform, to frame political alternatives, and thus to mark an oppositional stance. Undoubtedly, constructions of political opposition frequently-perhaps even primarily - draw their discursive repertoire from national discursive traditions. Indeed, they are to some extent compelled to do so in order to resonate with a domestic audience. Yet they also refer extensively to the international realm in order to establish opposition within a national political context. In this respect, the International acts as a framework for interpretation and discourse. It serves to render more contemporary the distinction between government and opposition in a national context. 


\section{The International and the Construction of Political Opposition}

Of course, autocracies are generally characterized by regulation of and restrictions on political communication. Nonetheless, except for in extreme cases, autocracies are not closed political spaces in which politics draws exclusively on narrowly national discourses. In fact, both autocratic governments and the oppositions that confront them use external sources in order to articulate their political programs and positions. They do so within the prevailing conditions of a global political system (Albert 2016). To some extent, such governments are required to invoke such reference points if they wish to avoid the risk of a crisis of legitimacy. Indeed, precisely those states that have arisen out of or are based on a narrative of anti-colonial mobilization frequently anchor their claim to legitimacy in an international dimension. In such cases, the goal of a better state and social life is often based on an international comparison.

Yet an opposition can also legitimize its reform proposals, and its criticism of the government, by pointing out domestic divergences from international standards. This comparison can focus both on wealthy states and on countries in a similar stage of development. The international dimension thus serves as a symbolic resource for justifying political positioning in the domestic domain. Of course, this can happen in many different ways. In autocracies, the degree of asymmetry, in terms of a particular actor's ability to publicly promote certain political positions, is variable.

The apt term "externalization" has been used by Schriewer in the context of his research on the diffusion of education policies. Externalization relates to the fact that domestic policies use international references in order to formulate and justify the demands for reform that underpin them. The International thus serves as a reservoir for generating political positions in the national context. A typical example of this can be seen in reform programs and demands in education policy. In this realm, political actors often refer to international standards in order to legitimate and implement their reforms. Such references to an external international environment are "expected to serve as 'lessons', to provide 'stimulative ideas' and 'new impetus to policy definition,' or to outline a 'frame reference' for the specification of reform options" (Schriewer 2008, p. 97).

It seems reasonable to assume that there is a partly structural need to externalize policy in this way, especially in competitive and electoral autocracies. It is precisely this need which creates an opportunity for the government, but above all for the opposition, to legitimize and even to articular their political ideas. Both 
oppositional and loyalist forces define themselves not only in national, but also in international, contexts: as anti-authoritarian, modernist, ecological, anti-globalist or feminist actors. Moreover, there exist limited international forces, such as cross-border ethno-nationalist or religious actors. The International is therefore not necessarily constructed and imagined in a uniform manner. These processes undoubtedly transpire in unique national environments traversed by particular government and opposition forces, which will be highly selective in their invocation of the International, endeavoring always to reflect national political discourses (Kluczewska 2019). The purpose of externalization, however, is primarily to avert legitimacy crises, or to gain legitimacy by invoking the International in the context of national political conflicts (2004, p. 204).

In summary, references to an international environment serve to establish oppositionality in several key respects. Above all, they legitimize demands for reform, whether limited or more far-reaching. In so doing, they facilitate the construction of an opposition to the government by formulating political alternatives that can be deemed both nationally and internationally acceptable. In the next section, we will draw on the relevant literature in international relations and transnational policy diffusion in order to distinguish three modes of externalization. These modes are used to construct opposition in the light of different "reference horizons" (Schriewer and Martinez 2004, p. 32) of the International.

\section{The International as a "Generalized Standpoint" and Provider of Norms}

The socio-constructivist literature of international relations has furnished us with the argument that states acquire and develop their identity, at least in part, through socialization (Finnemore 1993). For international relations, Mead's sociological perspective (1934) is adopted here. Mead argued that identity is developed through the engagement with significant others who convey norms of appropriate behavior. In this respect, the International appears as a normative referent horizon for actors to draw on in order to develop their identity and related political positions through the internalization of internationally institutionalized norms. It is well known, especially from human rights research, that this applies not only to states, but also to social actors. These actors behave as "norm entrepreneurs" (Keck and Sikkink 1998).

Oppositionality can thus be constructed by externalizing international norms that serve as the basis for a negative assessment of national governance. Classic examples of this include human-rights-based demands for political reform, but 
they also include demands that extend to the fulfilment of international standards in different policy fields, such as education or health. In this context, the International acts as an external "generalized standpoint" (Mead 1934, p. 138) from which reform demands appear legitimate. For example, the Khatami government's (1997-2005) conception of civil society was characterized by the norm that such a phenomenon is accompanied by political liberalization and democratic opposition. However, the promotion of such an ideal was brought to a halt after it turned out to be too regime-critical (Rivetti and Cavatorta 2013).

The Revolution of 1978 marked a turning point in Iranian politics. In the revolution's immediate aftermath, various models of collective living were heatedly discussed and differentiated (Schirazi 1998). Democracy, democratization, modernization, and social justice remained hot topics long after the consolidation of the Islamic Republic, even as discussion of more fundamental change was increasingly eliminated from the formal system and relegated to oppositional circles within civil society. The promotion of democratization through the strengthening of civil society became a concrete policy goal for loosely organized, intellectual oppositional circles. The prospect that this might develop into a more formal opposition to Khatami was one practicable strategy for keeping democratization systemically relevant even though it was a largely discredited political issue.

One of the main reasons for the success of this strategy was the broader establishment of a civil society in favor of democratic processes as an international norm. This was agreed upon by both moderate informal oppositional groups and by the reformist, institutionalized opposition (Rivetti and Cavatorta 2013). Both the formal and the informal opposition invoked international norms in order to articulate and legitimize their political goals. The formal opposition hoped to mobilize large groups of voters through such international legitimacy. Conversely, the informal opposition appealed to international norms in order to circumvent government attempts to delegitimize them.

However, the Iranian opposition was riven with profound disagreements over the envisioned nature of their reformed society. The opposition encompassed secular atheists and radical Islamists, pro-market capitalists and communists alike. Some looked to a reformed Islamic republic, others to a re-establishment of the Shah dictatorship, and still others to the establishment of a Western-oriented democracy. Within this normative melting pot, international norms offered a possibility for formulating content-related goals beyond ideological differences. Moreover, by referring to such "established" international norms, it seemed possible to avoid small-scale and ostensibly trivial discussions over details. 


\section{The International as a Space of Belonging}

In the case described above, oppositionality relates to a generalized reference horizon. But the difference-constructivist literature of international relations has also mapped out an alternative mode of identity construction. According to this literature, identity does not come about through identification with a generalized other. Instead, identity is constructed through the "discursive necessities that make identity dependent on difference" (Rumelili 2004, p. 33). What this means is that identity results from the construction of an otherness defined in negative terms.

Said (1978), for example, pointed out that stereotypes of the "Orient" have historically been essential to the construction of Western identity. The Orient serves as the cultural Other for the enlightened, liberal societies of the West. For the construction of European identities, the significance of a discursive juxtaposition of geopolitically or culturally defined outgroups has often been emphasized. Such outgroups might include the "East," "Islam" or even "America" (Diez 2004). Moreover, research on collective enemies has shown that identity can be based on the devaluation and securitization of others (Hansen 2006; Hagström 2015).

The International appears in this context as a reference horizon for the construction of specific, often transnational, "imagined communities" (Anderson 2006). Oppositionality can be built up through acts of identification with such imagined communities as opposed to the state's hegemonic identity constructions. This gives rise to cultural conflicts over the symbolic definition of national unity and belonging. These often play out between culturally defined groups, and between majority and minority groups.

A typical example of this are transnational religious communities. The narratives of such communities provide a source for opposing the state's hegemonic identity constructions. In Iran, such internationally informed constructions of identity often intermingle with ethno-national constructions to form oppositional identities. A clear example comes in the form of Sunni opposition to the predominantly Shia state. This is incorporated into Arab, as well as Kurdish and Afghan political identities. Indeed, such oppositional identities can be actively promoted by external patronage states. This is particularly the case if such identities are constructed through a sense of belonging to external collectives, and if these external imaginative spaces come to replace the formal state as the central point of reference. Consequently, demands for a re-imagination of the state are characteristic of such oppositional identities, as are demands for autonomy or secession. 
In conversations with Iranians, frequent references are made to Iranian peculiarities and to Iran's similarity with Western states. Phrases such as "Iran used to be like France" are commonly heard in taxis, for example (Field Notes).

A sense of connection to France or Germany is common among those Iranians who have lived there or have family members who migrated there. Indeed, remittances from these émigré Iranians often stabilize the socio-economic status of those family members who remained in Iran. As such, the social background of the speaker comes into play, as those with access to international travel and family networks are disproportionally better off socio-economically. At this point, a differentiation of the international reference horizon is already apparent. Some of those Iranians we spoke with made concrete references to their own (international) family history; to a sister in the US or an uncle in Sweden, for example (e.g. female student, September 4, 2017; male student, March 16, 2018). Such linkages seemed to enable explicit political comparisons, with the aforementioned countries serving as concrete points of reference.

However, in cases where a personal relationship to a specific country became more remote or non-existent, the political comparison was correspondingly more abstract. Instead of the Swedish social system, for example, "Western culture" served as a node of comparison. In a loyalist narrative, such references served to accentuate Iranian peculiarities (and thus the impossibility of implementing "Western" policies). Conversely, in a dissident narrative, "Western culture" became a basis for drawing similarities with Iran, and thus for identifying political goals.

Equally striking among those Iranians we conversed with was the evident lack of personal and discursive reference to neighboring countries. To be sure, those who had made pilgrimages to or had family links with Iraq made comparisons to it. Similarly, Afghanistan served as a notable benchmark, partly due to the presence of Afghan refugees, as well as the researcher's own Afghan roots, which prompted questions and guided conversations towards Afghani comparisons. However, Central Asian countries, or peripheral regions of the Near and Middle East, were rarely mentioned or scarcely present in conversations.

These communicative processes are more complex at Iran's periphery, where membership in the Iranian state is not necessarily a settled political issue. Ideal reference spaces can take the form of national and international communities, neighboring states, or other non-state communities. At the peripheries, distance from and affiliation to the nation-state is used to develop and articulate agency within a locally defined identity. This creates much more striking lines of conflict than in Teheran. 
For example, a basic conflict confronts the Kurdish communist who is in favor of centrally organized schooling, but at the same time approves of greater regional autonomy. This conflict can be resolved by referring to Iraqi Northern Kurdistan and the political model which prevails there. The availability of media, such as PKK/YPG television broadcasters, promotes such affiliations with neighboring countries. In such settings, then, oppositionality becomes multi-scalar and addresses the abstract nation-state through a local or trans-regional (e.g. Kurdish) identity. Meanwhile, it is also directed against local rulers who are considered excessively nationalistic or reactionary. There are the places where European political practices, or practices in a neighboring country, are most often invoked.

\section{The International as a Comparative Horizon}

A third reference horizon of the International is the focus of discussion in the literature on policy diffusion. As we have seen, the first such horizon presents the international as a kind of universalized empty canvas on which the internal social construction of opposition is projected. The second, meanwhile, takes specific international or transnational affiliations as the point of departure for opposition. The third, however, concerns itself with inter-societal comparisons.

As early as the 1960s, Bendix (1967) pointed out that the implementation of modernizing policies was closely linked to the fact that, since the nineteenth century, industrialized societies such as France and Britain have served as "reference societies," in Europe and across the world. In essence, these were examples to be followed. According to Bendix, in certain societies, such international comparisons gave rise to a perception of local backwardness. Consequently, the policies of the reference societies were increasingly adopted in order to achieve a similarly successful outcome. As a result, Bendix argued, this frequently led to externally induced social change in the "follower societies": "However, once the two eighteenth century revolutions had occurred, subsequent social changes were characterized by a precipitous increase in the speed and intensity of communication. Ideas and techniques have passed from 'advanced' to 'follower' societies .... Within a relatively short historical period there are few societies which have remained immune from these external impact upon their social structures" (Bendix 1967, p. 331).

Reference societies thus provide other societies with role models for formulating domestic political objectives and appropriate measures. Research on policy transfer has adopted his idea. Scholars working in this area have shown that the adaptation of policies in particular societies can be explained with refer- 
ence to their role models. But determining which societies function as reference societies requires taking many societal and cultural factors into consideration. Cross-border, seasonal migratory movements in the Caucasus, for example, caused particular groups in Iran (especially in the northwest) to be especially influenced by Russia-first the Tsarist Empire, then the Soviet Union. However, these influences diminished significantly after the establishment of Iran's national borders (Atabaki 2003).

Schriewer and Martinez (2004) have pointed out that, in the context of social change, the models of reference societies can lose their plausibility and give way to processes of reorientation whereby new role models are established. In the follower societies, references to such external models can underpin the articulation of reform demands and alternatives to the status quo across a range of socio-political fields. This applies both to the government, which can orient its policies toward such models, and to the opposition, which uses such comparisons to plausibly legitimate its calls for reform. Such comparisons frequently point to the perceived "success" of the reference societies.

In this respect, the otherness of the reference societies serves as an attractive reference point for the construction of opposition. The perceived political, cultural, or economic superiority of the reference society is used to construct opposition to a regime that appears woefully backward by comparison. And it is precisely the open and subjective nature of such perceptions that allows the opposition to draw on the reference society in order to formulate supposedly objective policies which are in fact riddled with preconceptions and assumptions. One of the earliest examples of this phenomenon was the Nahda cultural movement, which translated an often distorted image of European societies and European modernity into its own agendas and demands (Kurzman 2002; Kassab 2010).

However, such references need not be detailed or realistic. In fact, the invocation of reference societies as a comparative horizon for one's own political goals positively invites the idealization of these same societies. This can be with respect to, for example, the reference society's true economic power or the capacities of the state. In recent years, this tendency has been buttressed by the ostentatious display of luxurious lifestyles in social media. A few snapshots of a life in Los Angeles uploaded to Instagram are not infrequently taken as somehow representative of life in "the West." But when such images originate from the "Rich Kids of Tehran," they generate not exaltation but disapproval over their displays of conspicuous luxury. ${ }^{1}$ Iranians from beyond elite circles perceive this as offensive and unfair (Faghihi 2018). Yet little is changed with respect to the fundamental perception of the reference society. 
The otherness of reference societies is thus of considerable utility for oppositional constructions. Furthermore, however, especially radical opposition can be based on especially radical reference societies. The painting of an Israeli flag on a Tehran street was one such reference to an Other that is perceived as radically different. One actively reformist Iranian woman we conversed with remarked to me that she knew some especially radical (and thus, in her opinion, dubious) Iranians who exalted Israel as the most radical alternative to the existing regime. Members of these circles would hope to see a bloody overthrow of the Iranian regime, complete with "the hanging of the clergy," prompting a positive view of the USA as a possible interventionist power (female activist, March 17, 2018).

However, it is not only a reference society's difference that is relevant; its perceived "progressiveness" is also highly significant. Arab reference spaces hardly exist here. This is despite the fact that, as neighboring societies with historical, ethnic, and religious overlaps, Arab states positively invite comparison with Iran. In the West, such parallels are indeed drawn within the parameters of Middle Eastern Studies. But in Iran itself, such comparisons are marginal. Similarly, Central Asia provides yet another obvious ethnic and religious point of comparison. Yet hardly any of the Iranians we spoke with referred to this region. In fact, the mere mention of it tended to provoke surprise or indifference.

I discussed this later with some left-wing students at the University of Tehran. According to them, the "Sunni world" is taken into consideration only as a kind of supplicant (students, October 30, 2017). Otherwise, it hardly plays a role as a point of reference-in contrast to Western states. A telling example comes in the form of a reference to Turkey made by a family from the southwest of Iran whom we spoke to. They all agreed that they had once looked down upon Turkey, but that this was gradually changing because Turkey has become more progressive, more "European" (family conversation, March 8, 2018). In fact, the decisive factor here was not Turkey as an independent reference point, but the alleged proximity to a much more important reference point: Europe.

\section{Summary}

In autocracies, oppositionality can be constructed in various ways. Using the example of Iran, we have tried to show that international relations play an important role in allowing opponents of the regime to construct themselves as "oppositional" without resorting to institutionally prescribed mechanisms. A domestic context of acute authoritarianism provides few resources for the construction of opposition. In such circumstances, the International seems particularly important. 
Against this backdrop, we have distinguished three reference horizons that can be used by opponents in order to differentiate themselves from the regime in their communication. These include the construction of affiliations, references to international standards, and comparison with reference societies whose model they want to follow. Furthermore, these reference horizons are actualized via differing international communities and reference societies, with perceived proximity, progressiveness and otherness influencing who makes use of them and how. To what extent this translates into differences of program and practice, and whether the chosen points of reference impact these political programs, remains subject to future research.

In autocracies, these processes especially play out in everyday situations, beyond the realms of official political discourse. In this respect, the International provides symbolic resources for the articulation of reform demands not only within but beyond public space, in private or semi-public discourses. Research on opposition in autocracies has generally focused on conspicuous and spectacular examples of opposition, or on its integrative and stabilizing role. However, an exploration of the everyday construction of opposition is equally important for grasping the political dynamics of autocracies beyond the more glaring questions of regime change or regime consolidation. The article has attempted to outline a conceptual framework for carrying out such an exploration.

\section{Endnotes}

1. See https://www.instagram.com/therichkidsoftehran/?hl=de.

\section{References}

Aarts, P., and F. Cavatorta. 2013. Civil society in Syria and Iran. In Civil society in Syria and Iran: activism in authoritarian contexts, ed. P. Aarts and F. Cavatorta, 1-17. Boulder, CO: Lynne Rienner Publishers.

Albert, Mathias. 2016. A theory of world politics. Cambridge: Cambridge University Press.

Albrecht, H. 2005. How can opposition support authoritarianism? Lessons from Egypt. Democratization 12 (3): 378-397.

Anderson, Benedict. 2006. Imagined communities. Reflections on the origin and spread of nationalism. Revised. London: Verso.

Atabaki, T. 2003. Disgruntled guests: Iranian subaltern on the margins of the tsarist empire. International Review of Social History 48 (3): 401-426.

Bayat, A. 1997. Un-civil society: The politics of the 'informal people.' Third World Quarterly 18 (1): 53-72.

Bayat, A. 2013. Life as politics: How ordinary people change the Middle East. Stanford: Stanford University Press. 
Bendix, R. 1967. Tradition and modernity reconsidered. Comparative Studies in Society and History 9 (3): 292-346.

Buckles, G.T. 2019. Internal opposition dynamics and restraints on authoritarian control. British Journal of Politics 49 (3): 883-900.

Burnell, P. 2006. Autocratic opening to democracy: Why legitimacy matters. Third World Quarterly 27 (4): 545-562.

Carothers, T. 2002. The end of the transition paradigm. Journal of Democracy 13 (1): 5-21.

Cronin, Stephanie. 2007. Reform from above, resistance from below: The new order and its opponents in Iran, 1927-29. In The state and the subaltern: Modernization, society and the state in Turkey and Iran, ed. Touraj Atabaki, 71-94. London: I.B. Tauris.

Diez, T. 2004. Europe's others and the return of geopolitics. Cambridge Review of International Affairs 17 (2): 319-335.

Dukalskis, A., and J. Gerschewski. 2017. What autocracies say (and what citizens hear): Proposing four mechanisms of autocratic legitimation. Contemporary Politics 23 (3): 251-268.

Elseewi, T.A. 2011. A revolution of the imagination. International Journal of Communication 5: 1197-1206.

Faghihi, Rohollah. 2018. Yachts, fast cars and Instagram: Iran's rich kids enrage sanctions-hit citizens. London: Middle East Eye. https://www.middleeasteye.net/news/ yachts-fast-cars-and-instagram-irans-rich-kids-enrage-sanctions-hit-citizens. Accessed: 3 Sept 2019.

Finnemore, M. 1993. International organizations as teachers of norms: The United Nations educational, scientific, and cultural organization and science policy. International Organization 47 (4): 565-597.

Foran, John. 1994. The Iranian revolution of 1977-79: A challenge for social theory. In A century of revolution social movements in Iran, ed. John Foran, 160-188. Minneapolis: University of Minnesota Press.

Gerges, Fawaz A. 2015. Introduction: Contextualizing the Arab spring uprisings: Different regimes, different revolutions, and different trajectories. In Contentious politics in the Middle East. Popular resistance and marginalized activism beyond the Arab uprisings, Ed. Fawaz A. Gerges, 1-21. New York: Palgrave Macmillan

Hagström, L. 2015. The 'abnormal' state: Identity, norm/exception and Japan. European Journal of International Relations 21 (1): 122-145.

Hansen, Lene. 2006. Security as practice: Discourse analysis and the Bosnian War. London: Routledge.

Harders, Cilja, and C. J. König. 2013. Mobilization, repression, and coalitions: Understanding the dynamics of the Arab spring, discussion paper. Freie Universität Berlin. https://www.polsoz.fu-berlin.de/polwiss/forschung/international/vorderer-orient. Accessed 11 Aug 2019.

Joo, H. 2014. Hidden transcripts in marketplaces: Politicized discourses in the North Korean shadow economy. the Pacific Review 27 (1): 49-71.

Kassab, Elizabeth Suzanne. 2010. Contemporary Arab thought: cultural critique in comparative perspective. New York: Columbia University Press.

Keck, Margaret E., and K. Sikkink. 1998. Activists beyond borders: Advocacy networks in international politics. Ithaca: Cornell University Press. 
Kluczewska, K. 2019. How to translate 'good governance' into Tajik? An American good governance fund and norm localization in Tajikistan. Journal of Intervention and Statebuilding 13 (3): 1-20.

Kurzman, Charles. 2002. Modernist Islam, 1840-1940: A sourcebook. New York: Oxford University Press.

Kurzman, Charles. 2004. The unthinkable revolution in Iran. Cambridge: Harvard University Press.

Levitsky, S., and L.A. Way. 2002. The rise of competitive authoritarianism. Journal of Democracy 13 (2): 51-65.

Lewis, D. 2013. Civil society and the authoritarian state: Cooperation, contestation and discourse. Journal of Civil Society 9 (3): 325-340.

Luhmann, N. 1989. Theorie der politischen opposition. Zeitschrift Für Politik 36 (1): $13-26$.

Mead, George Herbert. 1934. Mind, self, and society. Chicago: University of Chicago Press.

Moaddel, Mansoor. 1994. Shi'i political discourse and class mobilization in the tobacco movement of 1890-92. In A century of revolution. Social movements in Iran, ed. John Foran, 1-20. Minneapolis: University of Minnesota Press.

Najmabadi, Afsaneh. 2007. Authority and agency: Revisiting women's activism during Reza Shah's period. In The state and the subaltern: Modernization, society and the state in Turkey and Iran, ed. Touraj Atabaki, 159-178. London: I.B. Tauris.

Rivetti, P., and F. Cavatorta. 2013. 'The importance of being civil society': Student politics and the reformist movement in Khatami's Iran. Middle Eastern Studies 49 (4): 645-660. https://doi.org/10.1080/00263206.2013.798311.

Rumelili, B. 2004. Constructing identity and relating to difference: Understanding the EU's mode of differentiation. Review of International Studies 30: 27-47.

Said, Edward. 1978. Orientalism. New York: Pantheon Books.

Schirazi, Asghar. 1998. The constitution of Iran: Politics and the state in the Islamic Republic. London: I.B. Tauris.

Schriewer, J.ürgen. 2008. Reference societies and model constructions: questioning international policy studies. In The public sector in transition, ed. J.J. Hesse, J.-E. Lane, and Y. Nishikawa, 85-102. Baden-Baden: Nomos.

Schriewer, J., and C. Martinez. 2004. Constructions of internationality in education. In The global politics of educational borrowing and lending, Ed. Gita Steiner-Khamsi, 29-53. New York: Teachers College Press, Columbia University.

Scott, James C. 1990. Domination and the arts of resistance. Hidden transcripts. New Haven: Yale University Press.

Sharifi, Majid. 2013. Imagining Iran: The tragedy of subaltern nationalism. Lanham: Lexington Books.

Steiner-Khamsi, Gita. 2004. Blazing a trail for policy theory and practice. In The global politics of educational borrowing and lending, Ed. Gita Steiner Khamsi, 201-220. New York: Teachers College Press, Columbia University.

Vinthagen, S., and A. Johansson. 2013. "Everyday resistance": Exploration of a concept and its theories. Resistance Studies Magazine. https://resistance-journal.org/wp-content/ uploads/2016/04/Vinthagen-Johansson-2013-Everyday-resistance-Concept-Theory.pdf. Accessed 11 Aug 2019. 
Zaccara, Luciano. 2014. Elections and Authoritarianism in the Islamic Republic of Iran. In Elections and democratization in the Middle East. The tenacious search for freedom, justice, and dignity, Eds. M. Hamad and K. al-Anani, 153-178. New York: Palgrave Macmillan.

Thorsten Bonacker is professor of peace and conflict studies at the Center for Conflict Studies at Philipps-Universität Marburg (Germany). He studied sociology, psychology, cultural studies and philosophy and holds a PhD from Universität Oldenburg (Germany). His research brings together perspectives from sociology and political science in the field of international relations. His work focusses in particular on postcolonial and postwar political conflicts, the role of victims in transitional justice as well as on sexual and reproductive rights as a global field of conflict.

Tareq Sydiq is a visiting fellow at the Center for Relational Studies on Global Crises at Chiba University as well as a researcher at the Center for Conflict Studies at PhilippsUniversität Marburg (Germany). He studied political science and sociology and is working on a $\mathrm{PhD}$ on Bottom-Up politics in authoritarian systems using Iran as a single-case study. His research interests include authoritarian states, protests and contestations as well as state formation.

Open Access This chapter is licensed under the terms of the Creative Commons Attribution 4.0 International License (http://creativecommons.org/licenses/by/4.0/), which permits use, sharing, adaptation, distribution and reproduction in any medium or format, as long as you give appropriate credit to the original author(s) and the source, provide a link to the Creative Commons license and indicate if changes were made.

The images or other third party material in this chapter are included in the chapter's Creative Commons license, unless indicated otherwise in a credit line to the material. If material is not included in the chapter's Creative Commons license and your intended use is not permitted by statutory regulation or exceeds the permitted use, you will need to obtain permission directly from the copyright holder.

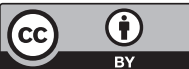

